\title{
The use of meadow-grass silage with formic acid in the nutrition of young calves
}

\author{
A. Baranowski and Krystyna Bidwell-Porębska
}

Institute of Genetic's and Animal Breeding. Polish Academy of Sciences

Jastrzetiec, 05-551 Mroków, Poland

(Received 13 June 1994; accepted 19 December 1994)

\begin{abstract}
Black-and-White bull calves aged 14 to 91 days werc fed rations differing in the type of roughage offered to appetite: hay (group $\mathrm{H}$ ) or meadow grass silage (group S) with $2 \mathrm{~kg} 80 \%$ formic acid/ton of fresh forage. Before weaning (days $14-42$ of age), the average daily intake of roughage dry matter and gross energy per $\mathrm{kg}^{0.75}$ was higher $(\mathrm{P} \leqslant 0.05)$ in group $\mathrm{H}$ than in group $\mathrm{S}(45.0 \mathrm{~g}$ and $1.1 \mathrm{MJ}$, vs. 41.1 $\mathrm{g}$ and $1.0 \mathrm{MJ}$, respectively). However, the differences in daily weight gains ( 623 and $583 \mathrm{~g}$ in groups $\mathrm{H}$ and $\mathrm{S}$ ) and feed utilization were not significant. After weaning (43 to 91 day of life), mean daily intake of nutrients and total energy was similar in both groups with daily weight gains reaching 478 and $502 \mathrm{~g}$, respectively for group $\mathrm{H}$ and $\mathrm{S}$. Mean body weight gains during the entire experimental period were the same in both groups and cqualled $530 \mathrm{~g}$.

The system of nutrition introduced in the present experiment may be useful for the rearing calves designed for future fattening based on roughages. However, due to the low level of $\mathrm{Mg}$ observed in blood plasma $(0.38 \mathrm{mmol} / \mathrm{l})$ of all the calves, the ration ought to be supplemented with a mineral mixture containing magnesium.
\end{abstract}

KEY WORDS: grass silage, calves, nutrition, performance

\section{INTRODUCTION}

Silage-based, hay-free rations have traditionally not been introduced into calf rations until weaning (Chapple, 1985; Leaver, 1973; Mcllmoyle, 1976; Steen, 1985). However, it has been demonstrated that good quality grass silage can be included in hay-free diets for young calves even of the age of two weeks (Bartholomew et al., 1981; Marsh, 1975, 1976). According to Marsh (1975) when fattened calves were provided with limited amounts of concentrates and grass silage fed to appetite, satisfactory weight gains were achieved and $35 \%$ less concentrate was consumed in comparison with traditional feeding regimens. Similar experiments have been conducted in Poland using maize silage (Piotrowski et al., 1988), red clover silage (Baranowski et al., 1989) and a mixed 
cereals x leguminous silage (Zdunczyk and Lewicki, 1989). Moreover, investigations have been conducted on the improvement of the value of grass silages for calves and included silages obtained from wilted herbage (Zduńczyk and Lewicki, 1988) and silages obtained from the second and third cut treated with Acidol (Bidwell-Porębska et al., 1987; Piotrowski et al., 1988). The present work aimed at determining the effects of feeding young calves on hay or silage obtained from the first cut of meadow grass treated with formic acid. As the feeding regimen may influence the mineral metabolism of calves (Bomba et al.,1993; Friedrich et al., 1996; Reece and Wahlstrom, 1972) on the last day of the experiment the level of macroelements was determined in the blood plasma of all the animals.

\section{MATERIAL AND METHODS}

Both, silage treated with $80 \%$ formic acid ( $2 \mathrm{~kg} /$ ton fresh grass) and hay used as the control feed (field-dried, followed by cold-air drying) were prepared from the first growth of meadow grass cut in flower (dominant species: Dactylis glomerata, Phleum pratense, Poa pratensis). Formic acid was added during harvesting with the aid of a Z-310 silos-combine and a HP-5 applicator from Ylö (Finland). The grass containing formic acid was placed in an experimental container made from concrete rings, protected against rain, snow and frost.

The experiment was conducted during late autumn on two groups of 12 Black-and-White bull calves, between 14 and 91 days of age. The animals were assigned to one of two groups differing in type of roughage offered to appetite. Group $\mathrm{H}$ received meadow hay, group $\mathrm{S}$ - grass silage. Until 42 days of age, each calf was given whole milk twice daily in an amount equivalent to $10 \%$ of its body weight, an average of $5.2 \mathrm{~kg} / \mathrm{day}$, and $300 \mathrm{~g}$ of concentrate CJ. After weaning on the 42 nd day of life each calf received $1 \mathrm{~kg}$ concentrate per day until day 91 . The $\mathrm{CJ}$ concentrate, supplemented with a mineral mixture Polfamix $\mathrm{C}$ at the rate of $10 \mathrm{~g}$ per calf, was offered once daily (at 7:30 AM). The roughages were offered to appetite at 7:30 AM and 4:30 PM. The calves were given water twice daily before hay or silage was offered. The intake of feeds was recorded daily. Samples of feeds were taken daily, pooled into weekly samples and subjected to chemical analysis. Blood was drawn from the zygomatic vein for determination of plasma $\mathrm{Na}, \mathrm{K}, \mathrm{Ca}$, inorganic $\mathrm{P}, \mathrm{Mg}$ and $\mathrm{Cl}$ contents.

The amount of basic nutrients in the feed samples was determined using conventional methods, gross energy in a KL-6 calorimeter. The organic acid content in silage was determined (Polish Standard, 1974), ammonia and $\mathrm{pH}$ according to Skulmowski (1974). The silage dry matter content was adjusted according to Fatianoff and Gouet (1969). Plasma $\mathrm{Na}, \mathrm{K}, \mathrm{Ca}$ and $\mathrm{Mg}$ levels were 
assayed by atomic mass absorption spectrometry, chloride $(\mathrm{Cl})$ and inorganic phosphorous (Png) by methods given by Pinkiewicz (1972).

The results were subjected to variance analysis using Harvey 1990 software.

\section{RESULTS AND DISCUSSION}

The silage (Table 1) had an optimal $\mathrm{pH}$ value (4.02) and a low protein degradation index, characteristic for well conserved grasses $\left(\mathrm{N}_{-} \mathrm{NH}_{3}\right.$ :total $\left.\mathrm{N}\right)$, equalling $6.75 \%$ (Voss, 1967). No butyric acid was found, while its low lactic and acetic acid levels ( 1.35 and $1.43 \%$ fresh matter) reflect the pattern of fermentation characteristic for formic acid (Jaakkola et al., 1991). In comparison with hay, the silage contained more crude protein (18.2 and $12.4 \%$, respectively) and less crude fibre (24.9 and $30.3 \%$ of DM, respectively). The natural structure of the silaged grasses, their colour and smell indicated that the silage was of good quality.

During the first period of rearing (14-42 days of age) the calves in group $\mathrm{H}$ consumed on average more dry matter daily $(\mathrm{P} \leqslant 0.05)$ than the group $\mathrm{S}$ $\left(45.0 \mathrm{~g} / \mathrm{kg} \mathrm{W}^{0.75}\right.$ vs. $41.1 \mathrm{~g} / \mathrm{kg} \mathrm{W}^{0.75}$; Table 2). Significant differences in favour of group $\mathrm{H}$ were also found in total organic matter intake $\left(41.9\right.$ and $38.7 \mathrm{~g} / \mathrm{kg} \mathrm{W}^{0.75}$ in groups $\mathrm{H}$ and $\mathrm{S}$, respectively) and in total gross energy intake (1.1 and 1.0 $\mathrm{MJ} / \mathrm{kg} \mathrm{W}^{0.75}$, respectively). The group $\mathrm{H}$ calves consumed more nutrients from concentrate and roughages than those in group S, but these differences were insignificant because of high individual variability in both groups. Similar differences in respect to intake of concentrate, hay and silage before weaning were found by Zduńczyk and Lewicki (1989).

During the second period of rearing (43-91 days of age), the mean intake of dry matter, organic matter and gross energy were similar in both groups. The calves in group $\mathrm{S}$ did, however, intake more crude protein in their rations $(\mathrm{P} \leqslant 0.05)$ than group $\mathrm{H}, 12.6$ vs $11.1 \mathrm{~g} / \mathrm{kg} \mathrm{W}^{0.75}$ because of the greater concentration of crude protein in the silage (Table 1).

No significant differences were observed between the groups in terms of feed intake and weight gains during the entire experiment. We found, in agreement with the results of other authors (Marsh, 1976; Zduńczyk and Lewicki, 1989), that limiting the ration of concentrate stimulates the intake of silage (the ratio of dry matter intake from concentrate to that from roughage in groups $\mathrm{H}$ and $\mathrm{S}$ was similar and equalled 1.3 and 1.4, respectively), and the silage, in spite of its low DM content $(18.9 \%)$ was comparable to hay as a source of nutrients for the calves.

During the period of feeding with milk the daily weight gains of the calves in group $\mathrm{S}$ were about $580 \mathrm{~g}$ and did not differ from the values found in calves fed red clover silage under similar conditions (Baranowski et al., 1989) or 
Table 3

Mean liveweight, daily gains and feed utilization by calves

\begin{tabular}{lcccc}
\hline Indices & Age, days & \multicolumn{3}{c}{ G R O U P S } \\
& & H & S & SEM \\
\hline Live weight, $\mathrm{kg}$ & 14 & 46.9 & 46.9 & 1.39 \\
& 42 & 64.3 & 63.1 & 1.74 \\
Daily gain, g & 91 & 87.8 & 87.7 & 2.47 \\
& $14-42$ & 623 & 583 & 43.2 \\
& $43-91$ & 478 & 502 & 22.8 \\
Feed utilization: & $14-91$ & 531 & 531 & 24.6 \\
dry matter, g/kg gain & $14-42$ & 1657 & 1764 & 193.1 \\
& $43-91$ & 3392 & 3319 & 180.1 \\
organic matter, g/kg gain & $14-91$ & 2630 & 2535 & 99.8 \\
& $14-42$ & 1549 & 1651 & 182.0 \\
& $43-91$ & 3103 & 3047 & 164.9 \\
crude protein, $\mathrm{g} / \mathrm{kg}$ gain & $14-91$ & 2380 & 2341 & 88.9 \\
& $14-42$ & 372 & 419 & 47.1 \\
& $43-91$ & 605 & 682 & 35.6 \\
gross energy, $\mathrm{MJ} / \mathrm{kg}$ gain & $14-91$ & 501 & 542 & 19.1 \\
& $14-42$ & 38.5 & 41.8 & 4.85 \\
& $42-91$ & 62.1 & 62.5 & 3.21 \\
& $14-91$ & 51.6 & 49.7 & 1.91 \\
\hline
\end{tabular}

cereal-leguminous silage (Zduńczyk and Lewicki, 1989). These gains were $40 \mathrm{~g}$ lower than those in group $\mathrm{H}$, but this difference was not statistically significant (Table 3).

During the second period of the experiment, between days 43 and 91 of age, the daily gains of the calves in group S were somewhat greater $(502 \mathrm{~g})$ than in group $\mathrm{H}(478 \mathrm{~g})$, but these differences were also found to be insignificant. Similar gains after weaning in calves fed limited amounts of concentrated feed $(1 \mathrm{~kg}$ per animal per day) and hay or silage from the second cut of meadow grasses (476 and $519 \mathrm{~g}$, respectively) were found in the calves studied by Piotrowski et al. (1988).

The dietary regimen used in this study did not, however, result in high daily gains, which overall averaged $530 \mathrm{~g}$ in both groups. The gains obtained in this experiment, as well as the feed utilization indices (no significant differences between the groups) confirm the conclusions reached in other studies (Bidwell-Porębska et al., 1987; Piotrowski et al, 1988; Zduńczyk and Lewicki, 1988; Zduńczyk and Lewicki, 1989; Buch, 1990) that these rations have a similar nutritional value, regardless of the roughages used, be it hay or silage.

The plasma $\mathrm{Na}, \mathrm{K}, \mathrm{Ca}$, inorganic $\mathrm{P}, \mathrm{Mg}$ and $\mathrm{Cl}$ levels (Table 4) did not differ significantly among the calves in both groups. The plasma mineral contents were 
TABLE 4

Minerals content in blood plasma, $\mathrm{mmol} / 1$

\begin{tabular}{lccc}
\hline Ingredient & $\mathrm{H}$ & G R O U P S & \\
& & $\mathrm{S}$ & $\mathrm{SEM}$ \\
\hline $\mathrm{Na}$ & 121 & 122 & 0.7 \\
$\mathrm{~K}$ & 3.8 & 3.8 & 0.05 \\
$\mathrm{Ca}$ & 2.6 & 2.4 & 0.06 \\
Inorganic P & 2.4 & 2.5 & 0.05 \\
$\mathrm{Mg}$ & 0.38 & 0.38 & 0.017 \\
$\mathrm{Cl}$ & 122 & 124 & 1.1 \\
\hline
\end{tabular}

within the normal ranges for three-month-old calves (Bouda and Jagoš, 1984; Dalton, 1967; Friedrich et al., 1986; Reece and Wahlstrom, 1972) with the exception of $\mathrm{Mg}$, the level of which $(0.38 \mathrm{mmol} / \mathrm{l})$ indicated subclinical hypomagnesemia (Ivins and Alcroft, 1969; Smith, 1957). The probable cause was insufficient intake with the diet (the limited amount of concentrate in the ration) additionally influenced by natural factors (low constitutional $\mathrm{Mg}$ reserves, low utilization of $\mathrm{Mg}$ in the feed) that intensify hypomagnesemia in calves (Bomba et al., 1993).

This experiment showed that the type of roughages given, hay or silage, does not have a significant effect on the performance of calves during rearing or on feed utilization by them between 14 and 91 days of age. The daily weight gains of these bull calves were relatively low, but comparable with those of calves fed

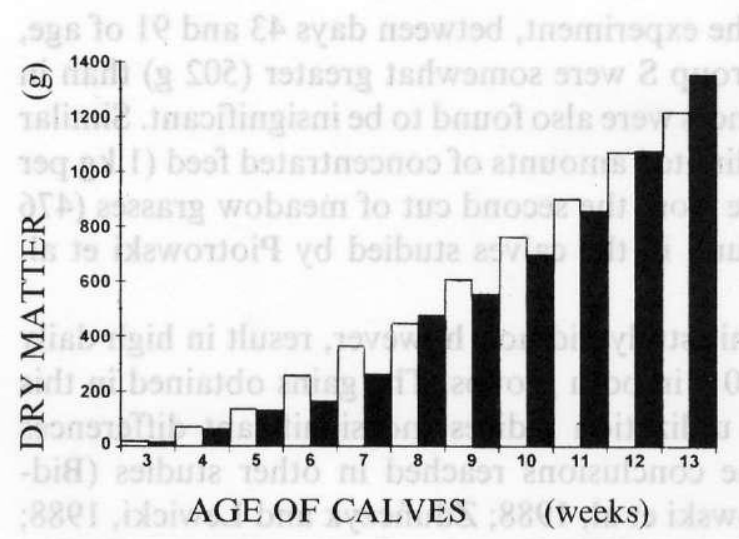

Group $\mathrm{H} \square$ hay $\quad$ Group S silage

Figure 1. Dry matter intake from roughages, g/calf/d 
limited rations of concentrates with various types of silages (Bidwell-Porębska et al., 1987; Piotrowski et al, 1988, Zduńczyk and Lewicki, 1988, 1989; Baranowski et al., 1989). Limiting the ration of concentrate CJ stimulated the consumption of roughages, especially silage. During the last week of the experiment (Fig. 1) more silage than hay was consumed (by 1357 and $1220 \mathrm{~g}$, respectively per calf per day). At the age of 3 months, the bull calves weighing about $88 \mathrm{~kg}$ ate about $7 \mathrm{~kg}$ silage daily and were well prepared for future fattening based on roughages. Because of the low plasma magnesium level in all of the calves, the rations should additionally be supplemented with a mineral mixture containing this element.

\section{REFERENCES}

Baranowski A., Bidwell-Porębska K., Piotrowski J., 1989. Red clover silage in calf nutrition. Evaluation and application (in Polish). Bydg. Tow. Nauk. Pr. Kom. Nauk Rol. Biol. Ser. B, 38, 75-85

Bartholomew P.W., McLauchlan M., Chestnutt D.M.B., 1981. Effect of unwilted and wilted silages and hay, supplemented with different amounts of concentrate, on live-weight gain of calves. Anim. Prod. 32, 307-313

Bidwell-Porębska K., Piotrowski J., Baranowski A., Krzyżewski J., 1987. Nutrient intake, weight gains and certain observations on rumen development in young calves reared on grass silage based diet. Anim. Sci. Pap. Rep. 2, 61-76

Bomba A., Králiček L., Žitñan R., Králičeková E., Poláček M., 1993. Hodnotenie úrovne minerálneho metabolizmu teliat $\mathrm{v}$ obdobi mlečnej výživy a odstavu na zaklade vybranych parametrov v krvi. Vet. Med. (Czech.) 38, 141-150

Bouda J., Jagoš P., 1984. Biochemical and hematological reference values in calves and their significance for health control. Acta Vet. Brno 53, 137-142

Bush R.S., 1990. The effect of hay and silage on growth and rumen function in young Holstein calves. Can. J. Anim. Sci. 71, 145-153

Chapple D.G., 1985. Feeding young calves on silage-only diets. Grass Forage Sci. 40, 237-238

Dalton R.G., 1967. Variations in calf plasma composition with age. Brit. Vet. J. 123, 48-52

Fatianoff N., Gouet P., 1969. Relation permettant de cooriger rapidement et avec précision la matière sèche des ensilages sèchés d l'étuve. Ann. Zootech. 18, 407-418

Friedrich M., Orowicz W., Piech H., 1986. Influence of different diet on some biochemical blood indicies in calves for the first four months of age. I. Mineral components and haematologic blood indices (in Polish). Pol. Arch. wet. 26, 181-193

Ivins L.N., Alcroft R., 1969. The effect of increased levels of dietary calcium and sodium on the development of hypomagnesaemia in milk-fed calves. Brit. Vet. J. 11, 547-559

Jaakkola S., Huhtanen P., Hissa K., 1991. The effect of cell wall degrading enzymes or formic acid on fermentation quality and on digestion of grass silage by cattle. Grass Forage Sci. 46, 75-87

Leaver J.D., 1973. Rearing of dairy cattle. 4. Effect of concentrate supplementation on the live-weight gain and feed intake of calves offered roughages ad libitum. Anim. Prod. 17, 43-52

Marsh R., 1975. The performance of early-weaned calves offered a high dry-matter silage supplemented with concentrates or dried grass. Anim. Prod. 21, 21-30

Marsh R., 1976. Intake by performance of early-weaned calves offered unwilted or wilted silage supplemented with a cereal and protein concentrate or dried grass. Anim. Prod. 22, 311-320 
McIlmoyle W.A.. 1976. Effect of silage additives on the intake and performance of male calves and steers. Anim. Prod. 22, 321-328

Polish Standard. 1974. Feeds. Methods of estimation the quality and nutritive value of silages (in Polish). BN-74/9162-01

Pinkiewicz. E., 1972. Basic laboratory investigations in animal diseases (in Polish). PWRiL, Warszawa

Piotrowski J., Bidwell-Porębska K., Baranowski A., Krzyżewski J., 1988. Intake, growth rate and digestibility in calves fed a restricted amount of concentrate and offered maiz silage or grass silage ad libitum from the second week of life. Anim. Sci. Pap. Rep. 4. 33-52

Reece W.O., Wahlstrom J.D., 1972. Variation in plasma composition of calves: relationship of electrolyte, glucose and urea nitrogen concentration to calf age, ration, and feeding time. Amer. J. Vet. Res. 33, 2175-2178

Skulmowski J., 1974. Methods of determination the composition and feeds quality (in Polish). PWRiL, Warszawa

Smith R.H., 1957. Calcium and magnesium metabolism in calves. Plasma levels and retention in milk-fed calves. Biochem. J. 67, 471-481

Steen R.W.J., 1985. Protein supplementation of silage-based diets for calves. Anim. Prod. 41, 293-300

Voss N., 1967. Untersuchungen über den Proteinabbau in Grass- und Luzernesilage. Wirt. Futter 13, 130-145

Zduńczyk Z., Lewicki Cz., 1988. Utility of wilted grass silage as the only roughage in feeding of calves (in Polish). XX Meeting, Comitee of Animal Feeding and Feed Management, KNZ PAN. Olsztyn, 27-29.06.1988

Zduńczyk Z., Lewicki Cz., 1989. Utility of corn-leguminous silage as the only roughage in feeding of calves (in Polish). Acta Acad. Agric. Techn. Olst. Zoot. 33, 71-81

\section{STRESZCZENIE}

\section{Zastosowanie kiszonki $\mathrm{z}$ porostu ląkowego $\mathrm{z}$ dodatkiem kwasu mrówkowego $\mathrm{w}$ żywieniu cieląt}

Cielęta-buhajki rasy ncb od 14 do 91 dnia zycia jywiono dawkami różniącymi się rodzajem skarmianej do woli paszy objętościowej - siana (Grupa H) lub kiszonki z 1 pokosu runi ląkowej (Grupa S) z dodatkiem $80 \%$ kwasu mrówkowego (2 kg na 1 tonę zielonki). W okresic żywienia mlecznego (14-42 dzień życia) średnie dzienne pobranie suchej masy i energii brutto na $1 \mathrm{~kg}$ metaboličnej masy ciala było większe $(P \leqslant 0.05)$ w Grupie $\mathrm{H}$ (odpowiednio $45.0 \mathrm{~g}$ i $1.1 \mathrm{MJ}$ ) niż $\mathrm{S}$ (odpowiednio $41.1 \mathrm{~g}$ i $1.0 \mathrm{MJ}$ ), lecz nie stwierdzono istotnych różnic między grupami w wykorzystaniu paszy i przyrostach cieląt, które w grupie H i S wynosiły odpowiednio $623 \mathrm{~g}$ i 583 g na sztukę dziennie. W drugim okresie żywienia, w którym skarmiano wyłącznie pasze stałe (43-91 dzień życia), średnie dzienne pobranie składników pokarmowych i energii brutto $w$ obydwóch grupach było podobne, a średnie dzienne przyrosty cieląt $\mathrm{w}$ grupic $\mathrm{H}$ i S wynosiły odpowiednio po 478 i $502 \mathrm{~g}$ (różnice nieistotne). Średnic przyrosty masy ciała cieląt w ciągu całego doświadcrenia byly w obydwóch grupach jednakowe i wynosily po $530 \mathrm{~g}$.

Przyjęty w doświadczeniu schemat żywienia buhajków, z ograniczonym udziałem paszy treściwej i kiszonki skarmianej do woli, może być przydatny w odchowie cieląt przeznaczonych do późnicjszcgo opasania, opartego na paszach objętościowych. Ze względu na obserwowany u wszystkich buhajków niski poziom Mg w osoczu krwi $(0.38 \mathrm{mmol} / \mathrm{l})$ skarmiane dawki pokarmowe powinny być urupełniane mieszanką mineralną zawierającą magnez. 